\title{
Public awareness and acceptance of COVID-19 vaccine: An online cross-sectional survey, conducted in the first phase of vaccination drive in India
}

\section{Arumuganainar Suresh ( $\nabla$ suresh.a@iar.ac.in )}

Department of Biological Sciences and Biotechnology, Institute of Advanced Research- The University for Innovation, Gandhinagar-382426, Gujarat, India https://orcid.org/0000-0002-3193-0345

Rocktotpal Konwarh ( rock1311@gmail.com )

Uniglobe Scientific Pvt. Ltd. 7/9, Kishan Garh, Vasant Kunj, New Delhi-110070, India https://orcid.org/0000-00034767-4531

\section{Anand Pratap Singh}

Uniglobe Scientific Pvt. Ltd. 7/9, Kishan Garh, Vasant Kunj, New Delhi-110070, India https://orcid.org/0000-00015077-9567

\section{Anand Krishna Tiwari}

Department of Biological Sciences and Biotechnology, Institute of Advanced Research- The University for Innovation, Gandhinagar-382426, Gujarat, India

\section{Research Article}

Keywords: Acceptance, COVID-19, Hesitance, Indians, Knowledge, Vaccine

Posted Date: April 5th, 2021

DOI: https://doi.org/10.21203/rs.3.rs-324238/v1

License: (c) (i) This work is licensed under a Creative Commons Attribution 4.0 International License. Read Full License 


\section{Abstract}

The context-specific, complex issue of 'vaccine hesitancy' is explicated in terms of delay or refusal of vaccination despite the availability of vaccine services. Although eleven million beneficiaries were administered the COVID-19 vaccine in India from 16th January 2021 till 20th February 2021, however, proportionately a low turnout has been registered in various parts of the country, possibly attributable to hesitance/apprehension towards the current vaccination. In this backdrop, we report the response (collected between Feb 1, 2021 and Feb 15, 2021) of 358 voluntary respondents who participated in an online questionnaire-based pan-India survey, executed to assess their knowledge and acceptance towards the current COVID-19 vaccination program in its first phase. The survey questionnaire consisted of demographic characteristics of the respondents and queries pertaining to knowledge ( 7 items) and acceptance (3 items). The overall correct rate and the average knowledge score of the participants were $78 \%$ and $5.46 \pm 1.4 / 7$ respectively. The acceptance score was $3.50 \pm 1.6 / 5$ while $70 \%$ of participants agreed against the $20 \%$ of respondents who neither agreed nor disagreed to take the vaccine. Around $66 \%$ believed that the vaccines, currently being administered in India are safe. Fear about possible side effects (44 \%) and inadequacy of comprehensive clinical trial data (29\%), seemed to be the major players in fortifying the vaccine hesitancy among the respondents, exhibiting negative acceptance. Although maximum respondents demonstrated a good level of knowledge (82\%) and acceptance (88\%), significant differences were observed among some demographic variables. In general, a positive correlation was observed between knowledge and acceptance against a negative correlation, observed in specific provinces. Despite the good acceptance and knowledge, a considerable fraction of the participants (30\%) expressed hesitancy. Counselling, mobilization, and feedback from vaccinated individuals about safety should be encouraged. However, due to the limited sample size, we must be cautious when generalizing these findings. Nevertheless, the major elucidations of this study may be utilized in planning vaccination campaigns in further phases.

\section{Introduction}

The global cataclysm, ushered in by COVID-19 needs no extensive description. Various measures including countrywide lockdowns have been adapted globally to control and contain the disease. Albeit, the endeavors to devise appropriate diagnostic and therapeutic strategies against the pandemic have escalated multifold (Konwarh, 2020a, b; Konwarh, 2021), the daily rise in the total number of confirmed cases and deaths seems incessant (globally: 129 million confirmed cases with 2.83 million deaths; India: 12.2 million confirmed cases with $163 \mathrm{~K}$ deaths as on 2 April 2021) (Worldometer, 2021). Amongst others, the hunt for safe and effective vaccines continues across multiple nations while a few countries including India have successfully developed vaccines in less than a year's time frame, started their trial, approved and permitted the mass vaccination drive (LSHTM, 2021).

The COVID-19 vaccination program kick started on 16th January, 2021 in India. The first group of beneficiaries included healthcare and frontline workers. The second group, comprising people over 60 years of age (as of January 1 st, 2022) and those in the age-bracket of (45-59) years with comorbid conditions started receiving vaccinations from March 1st, 2021 while vaccination for those above 45 years of age started from April 1st, 2021 (Ministry of Health and Family Welfare, Govt. of India, 2021). Covishield® (AstraZeneca's vaccine manufactured by Serum Institute of India) and Covaxin ${ }^{\circledR}$ (manufactured by Bharat Biotech Limited) are the two vaccines that have been granted emergency use authorization by the Central Drugs Standard Control Organization (CDSCO) in India. In the initial launching phase of the vaccination program, the beneficiaries were advised to receive two doses at a minimum time gap of 28 days. Although the second dose of Covaxin® can be taken four to six weeks after the first, however, the time gap between two doses of the Covishield vaccine has been extended from four-six weeks to four-eight weeks 
(Ministry of Health and Family Welfare, Govt. of India, 2021). The vaccine is free and participation in the vaccination drive is voluntary. One can register on the Co-WIN Portal and schedule his/her vaccination appointment or local government health workers at Corona Vaccination Centers (CVCs) can help the beneficiaries with on-the-spot registration, appointment, verification, and vaccination on the same day in case the latter fail to get themselves registered online. Despite these efforts on the governmental end, the public response, particularly, in the early days of the first phase of vaccination was no less than dismal. The overall turnout was only $53 \%$ on the first day, $44 \%$ on the second day and $48 \%$ on the third day post-registration. In the first three days, 6, 31,417 people (far below the expected figure) were vaccinated while $0.18 \%$ reported side-effects and nine people (0002\%) were admitted to hospitals for observation and treatment (The Hindu, 2021). The drive is being decelerated by low turnout, attributable to a concert of factors including concerns about the safety of the vaccine, technical problems with the software used for the online registration, and rapid dissemination of misinformation among the mass (The Guardian, 2021). The overall national turnout had averaged around $64 \%$ while merely $22 \%$ and $23 \%$ of the target beneficiaries in Tamil Nadu and Punjab, respectively were vaccinated in the first two days of the vaccination drive (The Guardian, 2021). Surprisingly, only $4 \%$ turned up for the second dose of the vaccine on February 13 (Hindustan Times, 2021).

The above figures suggest that people are either unaware or afraid/hesitant towards the current vaccination program. At this juncture, one may easily perceive the connotation of quoting vaccine hesitancy as a 'delay in approval or denial of vaccination' and one of the top ten global health risks, as propounded by the Strategic Advisory Committee of Immunization Experts from the World Health Organization (MacDonald, 2015). Vaccine hesitancy and misinformation in many countries stand as impediments in achieving coverage and population immunization (Larson et al., 2014; Lane et al., 2018). Governments and communities must gauge the existing levels of awareness and readiness to get a COVID-19 vaccine that is potentially safe and successful, besides identifying the backdrop of hesitancy towards the current vaccination program (DNAINDIA, 2021). Therefore, the objective of this pan-India online survey was to assess our citizens' awareness and acceptance of the current COVID-19 vaccination program. Although a couple of previous surveys were directed towards assessing the acceptance of the COVID-19 vaccine prior to the launch and use of the vaccine (Sharun et al. 2020; Gautam et al. 2020; Kazi Abdul and Khandaker Mursheda, 2020) among the mass, our study was conducted during the 1 st phase of the vaccination program in India. The results, presented in this work are based on the response, collected from a sample of 358 online voluntary participants from different states and union territories of India. It is envisaged that the outcome of this survey will definitely assist in decision making and policy framing to fortify the current COVID-19 vaccination program in the subsequent phases.

\section{Materials And Methods}

\section{Survey plan and Participants}

The time-frame of this cross-sectional survey was set from February 01, 2021 to February 15, 2021. During this period, the first phase of COVID-19 vaccination was initiated among the healthcare workers and frontline workers. The lockdown was relaxed, although citizens were advised to maintain social distancing, wear masks and wash hands. The nation also witnessed partial reopening of educational institutions in various states. It was not feasible as well as advisable to conduct any off-line survey during this period, therefore, we decided to collect the data online using Google form. A one-page poster (Electronic Supplementary Fig. ES1) was prepared and posted through various social media platforms like WhatsApp, Facebook, Twitter, and Telegram, based on the authors' network. The poster contained an introduction and objectives of the work, besides information about requirements on the part of the participants, nature of voluntary participation, declaration of anonymity and confidentiality, online link, and the invigilators' details. The respondents were Indian citizens, aged 18 years or more, who understood the content of the 
poster and voluntarily agreed to participate in the study without receiving any compensation or remuneration. An ecertificate was provided to the participants as a token of appreciation (directly delivered via e-mail), therefore, we had requested the submission of the name and e-mail address of each respondent through the Google form.

\section{Questionnaires and score}

We designed a survey questionnaire, based on the current situation. The questionnaire consisted of demographics of the participants, knowledge, and acceptance-attitude towards the current COVID-19 vaccination program in India. Demographic variables included gender, age, state, marital status, education status, occupation, area (urban vs. rural) and the state/union territory of residence (/province) (Table 1). A total of 7 questions, pertaining to the assessment of the knowledge about COVID-19 were framed (Table 2). These questions were primarily multiple options based or of true/false nature with an additional 'I don't know' choice. A correct answer was awarded 1 point and an incorrect/unknown answer, a 0 point. The total knowledge score ranged from 0 to 7; a cut-off score of < 4 was set as 'poor' and > 5, 'good' knowledge. A total of 3 questions for acceptance (Table 3) were prepared and rated on the 5points Likert scale ranging from strongly disagree (1), disagree (2), neutral (3), agree (4) and strongly agree (5). Five points were awarded to the responses, marked as 'strongly agree' with scores decreasing to 1 for the responses of 'strongly disagree', as far as the positive-acceptance questions were concerned. For the negative-acceptance questions, a score of 1 was awarded for the response- 'strongly agree', with the score increasing to 5 corresponding to the response, 'strongly disagree'. People who scored > 7 were classified as those with an attitude of 'positive' acceptance while the participants, scoring $<7$ were considered as those with a 'negative' acceptance-attitude towards the vaccination. 
Table 1

Demographic characteristics of the respondents $(n=358)$ who participated in the online survey, conducted to gauge their awareness and acceptance of the COVID-19 vaccine in India during the 1st phase of the vaccination drive

\begin{tabular}{|c|c|c|c|}
\hline \multicolumn{2}{|c|}{ Demographic characteristics } & \multirow{2}{*}{$\begin{array}{l}\mathbf{n} \\
184\end{array}$} & \multirow{2}{*}{$\begin{array}{l}\% \\
51.4\end{array}$} \\
\hline Gender & Male & & \\
\hline & Female & 173 & 48.3 \\
\hline & Others & 1 & 0.3 \\
\hline \multirow[t]{3}{*}{ Age } & $18-29$ & 267 & 74.6 \\
\hline & $30-49$ & 90 & 25.1 \\
\hline & $50-69$ & 1 & 0.3 \\
\hline \multirow[t]{4}{*}{ Marital status } & Married & 89 & 24.9 \\
\hline & Unmarried & 262 & 73.2 \\
\hline & Others & 4 & 1.1 \\
\hline & Not mentioned any & 3 & 0.8 \\
\hline \multirow[t]{5}{*}{ Education status } & $<12$ th grade & 13 & 3.6 \\
\hline & UG (holding or pursuing) & 137 & 38.3 \\
\hline & PG (holding or pursuing) & 163 & 45.5 \\
\hline & Ph.D. (holding or pursuing) & 42 & 11.7 \\
\hline & Not mentioned any & 3 & 0.8 \\
\hline \multirow[t]{5}{*}{ Occupation } & Student & 219 & 61.2 \\
\hline & Private job & 95 & 26.5 \\
\hline & Government Job & 15 & 4.2 \\
\hline & Health workers & 11 & 3.1 \\
\hline & Others (self, unemployed) & 18 & 5.0 \\
\hline \multirow[t]{3}{*}{ Area } & Urban & 278 & 77.7 \\
\hline & Rural & 77 & 21.5 \\
\hline & Not mentioned any & 3 & 0.8 \\
\hline \multirow[t]{6}{*}{ State } & Andaman and Nicobar Islands & 2 & 0.6 \\
\hline & Arunachal Pradesh & 1 & 0.3 \\
\hline & Assam & 69 & 19.3 \\
\hline & Bihar & 5 & 1.4 \\
\hline & Chhattisgarh & 4 & 1.1 \\
\hline & Dadra and Nagar Haveli and Daman and Diu & 1 & 0.3 \\
\hline
\end{tabular}




\begin{tabular}{|c|c|c|}
\hline Demographic characteristics & $\mathbf{n}$ & $\%$ \\
\hline Delhi & 12 & 3.4 \\
\hline Gujarat & 126 & 35.2 \\
\hline Haryana & 1 & 0.3 \\
\hline Himachal Pradesh & 1 & 0.3 \\
\hline Jharkhand & 7 & 2.0 \\
\hline Karnataka & 2 & 0.6 \\
\hline Kerala & 2 & 0.6 \\
\hline Madhya Pradesh & 7 & 2.0 \\
\hline Maharashtra & 6 & 1.7 \\
\hline Manipur & 1 & 0.3 \\
\hline Meghalaya & 2 & 0.6 \\
\hline Odisha & 2 & 0.6 \\
\hline Puducherry & 2 & 0.6 \\
\hline Punjab & 2 & 0.6 \\
\hline Rajasthan & 7 & 2.0 \\
\hline Tamil Nadu & 44 & 12.3 \\
\hline Telangana & 1 & 0.3 \\
\hline Uttar Pradesh & 48 & 13.4 \\
\hline Uttarakhand & 2 & 0.6 \\
\hline West Bengal & 1 & 0.3 \\
\hline
\end{tabular}


Table 2

Knowledge and awareness about COVID-19 vaccination among the participants $(n=358)$ during the 1 st phase of vaccination

\begin{tabular}{|c|c|c|c|c|c|}
\hline \multicolumn{2}{|c|}{ Questions, pertaining to knowledge } & \multicolumn{2}{|c|}{ Correct } & \multicolumn{2}{|c|}{ Incorrect } \\
\hline & & $\mathbf{n}$ & $\%$ & $\mathbf{n}$ & $\%$ \\
\hline K1 & $\begin{array}{l}\text { Do you know that the COVID-19 vaccination program started in India on the } \\
16 \text { th of January } 2021 \text { ? }\end{array}$ & 346 & 96.6 & 11 & 3.1 \\
\hline K2 & $\begin{array}{l}\text { Are you aware of the fact that the Indian government is using } 2 \text { types of } \\
\text { vaccines, namely, Covaxin and Covishield in its COVID-19 vaccination } \\
\text { program? }\end{array}$ & 314 & 87.7 & 43 & 12.0 \\
\hline K3 & Which vaccine is developed in India? & 228 & 63.7 & 130 & 36.3 \\
\hline K4 & Who are being administered with the COVID-19 vaccine in the first phase? & 327 & 91.3 & 31 & 8.7 \\
\hline K5 & $\begin{array}{l}\text { Do you know that two doses of the COVID-19 vaccine, } 28 \text { days apart, need to } \\
\text { be administered to an individual to complete the vaccination schedule? }\end{array}$ & 273 & 76.3 & 82 & 22.9 \\
\hline K6 & The COVID - 19 vaccine is free in India & 232 & 64.8 & 126 & 35.2 \\
\hline K7 & $\begin{array}{l}\text { In India, getting vaccinated for COVID-19 is voluntary in nature, and not } \\
\text { mandatory }\end{array}$ & 236 & 65.9 & 120 & 33.5 \\
\hline
\end{tabular}

Table 3

Acceptance of COVID-19 vaccination among the participants $(n=358)$ during the 1 st phase of vaccination

\begin{tabular}{|c|c|c|c|c|c|c|c|c|c|c|c|c|c|c|}
\hline \multicolumn{2}{|c|}{$\begin{array}{l}\text { Questions, } \\
\text { pertaining to } \\
\text { acceptance }\end{array}$} & \multicolumn{2}{|c|}{$\begin{array}{l}\text { Strongly } \\
\text { disagree } \\
\text { (1) }\end{array}$} & \multicolumn{2}{|c|}{$\begin{array}{l}\text { Disagree } \\
\text { (2) }\end{array}$} & \multicolumn{2}{|c|}{$\begin{array}{l}\text { Neutral } \\
\text { (3) }\end{array}$} & \multicolumn{2}{|c|}{ Agree (4) } & \multicolumn{2}{|c|}{$\begin{array}{l}\text { Strongly } \\
\text { agree (5) }\end{array}$} & \multirow[t]{2}{*}{$\begin{array}{l}\text { Average } \\
\text { score }\end{array}$} & \multirow[t]{2}{*}{ SD } & \multirow[t]{2}{*}{$\begin{array}{l}P \text { - } \\
\text { value }\end{array}$} \\
\hline & & $\mathrm{n}$ & $\%$ & $\mathrm{n}$ & $\%$ & $\mathrm{n}$ & $\%$ & $\mathrm{n}$ & $\%$ & $\mathrm{n}$ & $\%$ & & & \\
\hline $\mathrm{A} 1$ & $\begin{array}{l}\text { I will } \\
\text { take } \\
\text { the } \\
\text { COVID- } \\
19 \\
\text { vaccine }\end{array}$ & 11 & 3.1 & 24 & 6.8 & 75 & 21.1 & 100 & 28.2 & 145 & 40.8 & 3.97 & 1.17 & $\begin{array}{l}<.001 \\
0.00\end{array}$ \\
\hline $\mathrm{A} 2$ & $\begin{array}{l}\text { The } \\
\text { Indian } \\
\text { COVID- } \\
19 \\
\text { vaccine } \\
\text { is safe } \\
\text { to use }\end{array}$ & 8 & 2.2 & 21 & 5.9 & 93 & 26.1 & 117 & 32.9 & 117 & 32.9 & 3.88 & 1.01 & $\begin{array}{l}<.001 \\
0.00\end{array}$ \\
\hline A3 & $\begin{array}{l}\text { I am } \\
\text { afraid } \\
\text { of } \\
\text { taking } \\
\text { the } \\
\text { COVID- } \\
19 \\
\text { vaccine }\end{array}$ & 95 & 26.6 & 74 & 20.7 & 79 & 22.1 & 68 & 19.0 & 41 & 11.5 & 2.68 & 1.82 & $\begin{array}{l}<.001 \\
0.00\end{array}$ \\
\hline
\end{tabular}

\section{Ethical considerations}

All procedures performed in this study, involving human participants, complied with the institutional ethical standards and were approved by the Ethical Committee of the Institute of Advanced Research, Gujarat, India. Moreover, the 
study was designed and conducted in accordance with the ethical principles established by the "Committee on Publication Ethics (COPE)" guidelines to handle publication ethics. Confidentiality of the participants' information was ensured throughout the study. The online pages for the self-administered questionnaire could be accessed by the participants for attempting and completion, subjected to indication (through a click on 'Yes' button) of consent for voluntary participation.

\section{Statistical analysis}

The data collected from the survey were collated while the incomplete and repeated/multiple responses were deleted. The first completed responses were considered as accurate. The descriptive statistics and one-way analysis of variance (ANOVA) or Chi-square test as appropriate were performed using Microsoft Excel to determine the differences between the groups for selected demographic variables and their knowledge and acceptance towards COVID-19 vaccination. Regression tests were applied to assess any correlation between knowledge and acceptance scores. The statistical significance level was set at $p<0.05$.

\section{Results}

\section{Demographic characteristics}

A total of 376 participants attempted the survey questionnaire. Among these, 18 responses were incomplete or repeated attempts, and as such excluded. Among the valid responses, collected from 358 participants, a correct response rate of $95.2 \%$ was documented. Almost equal representation of either gender (albeit, males had a slightly higher representation of $51.4 \%$ ) was registered while the majority of the respondents were within the age group of 18-29 years (74.6\%) and unmarried (73.2 \%) (Table 1). Most of the respondents either held or pursued college-level education (95.5\%) against 13 participants with school education ( $<12$ th grade). More than half of the respondents $(6$ out of 10 ) were students, followed by people in private jobs (26.5\%), government jobs (4.2\%), and healthcare sector $(3.1 \%)$ respectively. The participation was primarily documented from 26 states with maximum representation from Gujarat (126), followed by Assam (69), Uttar Pradesh (48), and Tamil Nadu (44), and rest (71) from other 22 states. Among this, eight out of ten were from the urban area. The various other demographic characteristics are shown in Table 1.

\section{Assessment of knowledge}

The average knowledge score for the participants was $5.46 \pm 1.35$ (range: $0-7$ ) (Table 4). The overall correct answer rate for the knowledge questionnaire was $78 \%(5.48 / 7 * 100)$. As shown in Table 2 , almost all the participants (97.7 $\%$ ) knew that the 1 st phase of vaccination started on 16th January, 2021. However, one third of the respondents were unaware of the Indian vaccine candidate, the attribute of voluntary/non-mandatory participation in the vaccination program and free-of-cost availability-provisions of the vaccines in India. Nearly a quarter of the participants (22.9\%) did not know the requirement of a second shot, post 4 weeks of the 1 st administration to complete the vaccination schedule. Nine out of ten answered correctly about the two types of vaccines, currently being administered in the country. The respondents were aware of the fact that the beneficiaries in the 1st phase of the vaccination program were the healthcare and frontline workers. The knowledge score significantly $(p<0.05)$ differed among the various demographic variables (Table 4) except the gender and the area (urban vs. rural) of dwelling. Significant difference was documented for the knowledge level vis-à-vis the demographical variables of age, marital status, education status, and occupation category. In overall, two out of ten exhibited poor knowledge level. This was associated more with the participants of the feminine gender, young age (18-29), lesser education status, students' category and 
those dwelling in the rural area. When asked about the source of information about the COVID-19 vaccination schedule in India, around $45 \%$ and $33 \%$ chose the options TV and social media, respectively (Fig. 1).

Table 4

Distribution of knowledge and acceptance scores across the various demographic variables of the participants ( $\mathrm{n}=$ 358) towards COVID-19 vaccine during the 1st phase of vaccination

\begin{tabular}{|c|c|c|c|c|c|c|c|c|c|}
\hline \multicolumn{2}{|c|}{ Demographic characteristics } & \multicolumn{2}{|c|}{$\begin{array}{l}\text { Knowledge score } \\
\text { (mean } \pm \text { SD) }\end{array}$} & \multirow{3}{*}{$\begin{array}{l}\begin{array}{l}F- \\
\text { value }\end{array} \\
2.34\end{array}$} & \multirow{3}{*}{$\begin{array}{l}\begin{array}{l}p- \\
\text { value }\end{array} \\
0.127\end{array}$} & \multicolumn{2}{|c|}{$\begin{array}{l}\text { Acceptance score } \\
\text { (mean } \pm \text { SD) }\end{array}$} & \multirow{3}{*}{$\begin{array}{l}\begin{array}{l}F- \\
\text { value }\end{array} \\
4.78\end{array}$} & \multirow{3}{*}{$\begin{array}{l}\begin{array}{l}p- \\
\text { value }\end{array} \\
< \\
0.05\end{array}$} \\
\hline \multirow[t]{2}{*}{ Gender } & Male & 5.57 & 1.32 & & & 3.83 & 0.95 & & \\
\hline & Female & 5.35 & 1.38 & & & 3.62 & 0.88 & & \\
\hline \multirow[t]{2}{*}{ Age } & $18-29$ & 5.29 & 1.40 & \multirow[t]{2}{*}{19.06} & \multirow{2}{*}{$\begin{array}{l}< \\
0.001\end{array}$} & 3.68 & 0.89 & \multirow[t]{2}{*}{2.37} & \multirow[t]{2}{*}{0.124} \\
\hline & $30-49$ & 5.99 & 1.07 & & & 3.85 & 1.02 & & \\
\hline \multirow{2}{*}{$\begin{array}{l}\text { Marital } \\
\text { status }\end{array}$} & Married & 6.03 & 1.03 & \multirow[t]{2}{*}{22.68} & \multirow{2}{*}{$\begin{array}{l}< \\
0.0001\end{array}$} & 3.81 & 1.03 & \multirow[t]{2}{*}{1.45} & \multirow[t]{2}{*}{0.229} \\
\hline & Unmarried & 5.29 & 1.00 & & & 3.68 & 0.89 & & \\
\hline \multirow{4}{*}{$\begin{array}{l}\text { Education } \\
\text { status }\end{array}$} & $<12$ th grade & 4.62 & 1.71 & \multirow[t]{4}{*}{6.10} & \multirow{4}{*}{$\begin{array}{l}< \\
0.001\end{array}$} & 3.72 & 1.07 & \multirow[t]{4}{*}{2.23} & \multirow[t]{4}{*}{0.086} \\
\hline & UG & 5.32 & 1.40 & & & 3.87 & 0.89 & & \\
\hline & $P G$ & 5.49 & 1.28 & & & 3.61 & 0.92 & & \\
\hline & Ph.D. & 6.14 & 0.98 & & & 3.62 & 1.00 & & \\
\hline \multirow[t]{5}{*}{ Occupation } & Student & 5.28 & 1.39 & \multirow[t]{5}{*}{3.97} & \multirow[t]{5}{*}{$<0.01$} & 3.70 & 0.85 & \multirow[t]{5}{*}{1.26} & \multirow[t]{5}{*}{0.285} \\
\hline & Private job & 5.79 & 1.19 & & & 3.79 & 1.01 & & \\
\hline & Government Job & 6.27 & 0.80 & & & 4.09 & 1.09 & & \\
\hline & Health workers ${ }^{2}$ & 5.64 & 1.43 & & & 3.48 & 1.34 & & \\
\hline & $\begin{array}{l}\text { Others (self, } \\
\text { unemployed) }\end{array}$ & 5.22 & 1.44 & & & 3.48 & 0.89 & & \\
\hline \multirow[t]{5}{*}{ State } & Assam & 5.07 & 1.43 & \multirow[t]{5}{*}{3.39} & \multirow[t]{5}{*}{$<0.01$} & 3.58 & 0.83 & \multirow[t]{5}{*}{5.39} & $<$ \\
\hline & Delhi & 5.17 & 1.40 & & & 4.36 & 0.85 & & \\
\hline & Gujarat & 5.35 & 1.43 & & & 3.80 & 0.83 & & \\
\hline & Tamil Nadu & 5.93 & 1.26 & & & 3.29 & 1.11 & & \\
\hline & Uttar Pradesh & 5.67 & 1.12 & & & 3.90 & 0.82 & & \\
\hline Area & Urban & 5.49 & 1.31 & 0.37 & 0.543 & 3.70 & 0.97 & 0.51 & 0.476 \\
\hline & Rural & 5.39 & 1.46 & & & 3.79 & 0.74 & & \\
\hline $\begin{array}{l}\text { Overall score } \\
\text { (Min-Max) }\end{array}$ & verage \pm SD & 5.46 & $5(0-7)$ & & & 3.50 & $2(1.33-5)$ & & \\
\hline
\end{tabular}

\section{Assessment of vaccine acceptance}

The average acceptance score for the participants was 3.50. \pm 1.62 (range: 1.33-5) (Table 4). Seven out of ten responded that they will take the COVID-19 vaccine, while one out of ten disagreed, and two out of ten chose neither. 
One fourth of the respondents chose neither to agree nor disagree about the safety of the vaccines. However, $65 \%$ seconded that the vaccines were safe to use while $8 \%$ voiced the other way. Though $70 \%$ respondents agreed to get vaccinated, $20 \%$ opted neither to agree nor disagree about taking the vaccine. Besides, $30 \%$ asserted that they were afraid of taking the COVID-19 vaccine while a neutral-attitude was noted for around $22 \%$. Responding to the query, 'Why are you hesitant/afraid to take the COVID-19 vaccine?', around $44 \%$ participants mentioned that their point of apprehension was the plausible side effect while three out of ten quoted the insufficiency of clinical trial data, on the other hand, a quarter of the respondents said 'I don't know' (Fig. 2). The acceptance score significantly $(p<0.05)$ differed among the gender and state category, while the difference was insignificant across other variables (Table 4). The acceptance level significantly $(p<0.05)$ differed across the states and area category, while the difference was insignificant across other variables (Table 5). Around 9 out of 10 exhibited positive acceptance level. Comparatively greater negative acceptance level was evident among the females, more aged (30-49), married, highly educated (Ph.D.), healthcare workers, and urban area dwellers. Regression tests revealed a significant positive linear correlation between knowledge and acceptance $(r=0.215, p<0.0001)$ (Table 6). 
Table 5

Knowledge and acceptance levels across demographic variables of the participants $(n=358)$ towards COVID-19 vaccine during the 1 st phase of vaccination

\begin{tabular}{|c|c|c|c|c|c|c|c|c|c|c|c|}
\hline \multicolumn{2}{|c|}{ Demographic characteristics } & \multicolumn{4}{|c|}{ Knowledge level } & \multirow{3}{*}{$\begin{array}{l}p- \\
\text { value }\end{array}$} & \multicolumn{4}{|c|}{ Acceptance level } & \multirow{3}{*}{$\begin{array}{l}p- \\
\text { value }\end{array}$} \\
\hline & & \multicolumn{2}{|c|}{ Poor } & \multicolumn{2}{|c|}{ Good } & & \multicolumn{2}{|c|}{ Negative } & \multicolumn{2}{|c|}{ Positive } & \\
\hline & & $\mathbf{n}$ & $\%$ & $\mathbf{n}$ & $\%$ & & $\mathbf{n}$ & $\%$ & $\mathbf{n}$ & $\%$ & \\
\hline \multirow[t]{2}{*}{ Gender } & Male & 34 & 18.5 & 150 & 81.5 & 0.279 & 18 & 9.8 & 165 & 90.2 & 0.487 \\
\hline & Female & 40 & 23.0 & 133 & 76.9 & & 21 & 12.1 & 152 & 87.9 & \\
\hline \multirow[t]{2}{*}{ Age } & $18-29$ & 68 & 25.7 & 197 & 74.3 & $<0.001$ & 29 & 10.9 & 237 & 89.1 & 0.732 \\
\hline & $30-49$ & 6 & 6.7 & 84 & 93.3 & & 11 & 12.2 & 79 & 87.8 & \\
\hline \multirow[t]{2}{*}{$\begin{array}{l}\text { Marital } \\
\text { status }\end{array}$} & Married & 4 & 4.5 & 85 & 95.5 & $\begin{array}{l}< \\
0.0001\end{array}$ & 11 & 12.4 & 78 & 87.6 & 0.673 \\
\hline & Unmarried & 67 & 25.5 & 196 & 74.5 & & 28 & 10.7 & 233 & 89.3 & \\
\hline \multirow{4}{*}{$\begin{array}{l}\text { Education } \\
\text { status }\end{array}$} & $<12$ th grade & 4 & 30.8 & 9 & 69.2 & $<0.05$ & 1 & 8.3 & 11 & 91.7 & 0.436 \\
\hline & $\begin{array}{l}\text { UG (holding or } \\
\text { pursuing) }\end{array}$ & 37 & 27.0 & 100 & 73.0 & & 11 & 8.0 & 126 & 92.0 & \\
\hline & $\begin{array}{l}\text { PG (holding or } \\
\text { pursuing) }\end{array}$ & 30 & 18.4 & 133 & 81.6 & & 22 & 13.5 & 141 & 86.5 & \\
\hline & $\begin{array}{l}\text { Ph.D. (holding or } \\
\text { pursuing) }\end{array}$ & 2 & 4.8 & 40 & 95.2 & & 6 & 14.3 & 36 & 85.7 & \\
\hline \multirow[t]{5}{*}{ Occupation } & Student & 58 & 26.5 & 161 & 73.5 & $<0.01$ & 20 & 9.1 & 199 & 90.9 & 0.342 \\
\hline & Private job & 11 & 11.6 & 84 & 88.4 & & 11 & 11.7 & 83 & 88.3 & \\
\hline & Government Job & 0 & 0.0 & 15 & 100.0 & & 2 & 13.3 & 13 & 86.7 & \\
\hline & Health workers & 2 & 18.2 & 9 & 81.8 & & 3 & 27.3 & 8 & 72.7 & \\
\hline & $\begin{array}{l}\text { Others (self, } \\
\text { unemployed) }\end{array}$ & 2 & 11.8 & 15 & 88.2 & & 3 & 16.7 & 15 & 83.3 & \\
\hline \multirow[t]{5}{*}{ State } & Assam & 19 & 27.5 & 50 & 72.5 & 0.082 & 7 & 10.1 & 62 & 89.9 & \\
\hline & Delhi & 3 & 25.0 & 9 & 75.0 & & 0 & 0.0 & 11 & 100.0 & $<.01$ \\
\hline & Gujarat & 34 & 27.0 & 92 & 73.0 & & 9 & 7.1 & 117 & 92.9 & \\
\hline & Tamil Nadu & 6 & 13.6 & 38 & 86.4 & & 11 & 25.0 & 33 & 75.0 & \\
\hline & Uttar Pradesh & 5 & 10.6 & 42 & 89.4 & & 3 & 6.3 & 45 & 93.8 & \\
\hline \multirow[t]{2}{*}{ Area } & Urban & 55 & 19.7 & 224 & 80.29 & 0.481 & 36 & 13.0 & 241 & 87.0 & $\begin{array}{l}< \\
0.01\end{array}$ \\
\hline & Rural & 18 & 23.4 & 59 & 76.62 & & 2 & 2.6 & 75 & 97.4 & \\
\hline
\end{tabular}




\begin{tabular}{|c|c|c|c|c|c|c|c|c|c|c|}
\hline \multirow{3}{*}{ Demographic characteristics } & \multicolumn{4}{|c|}{ Knowledge level } & \multirow{2}{*}{$\begin{array}{l}p- \\
\text { value }\end{array}$} & \multicolumn{4}{|c|}{ Acceptance level } & \multirow{2}{*}{$\begin{array}{l}p- \\
\text { value }\end{array}$} \\
\hline & \multicolumn{2}{|c|}{ Poor } & \multicolumn{2}{|c|}{ Good } & & \multicolumn{2}{|c|}{ Negative } & \multicolumn{2}{|c|}{ Positive } & \\
\hline & $\mathrm{n}$ & $\%$ & $\mathbf{n}$ & $\%$ & & $\mathbf{n}$ & $\%$ & $\mathbf{n}$ & $\%$ & \\
\hline Average (\%) & & 17.8 & & 82.2 & & & 11.9 & & 88.1 & \\
\hline
\end{tabular}

Table 6

Correlation between knowledge and acceptance towards the COVID-19 vaccine in India during the 1st phase of vaccination-

drive

\begin{tabular}{|lll|}
\hline Variable & Correlation Coefficient & $\boldsymbol{p}$-value \\
\hline Knowledge-Acceptance & 0.215 & $<0.0001$ \\
\hline
\end{tabular}

\section{Discussion}

Since the first quarter of 2020, the world has witnessed an unprecedented catastrophe in the form of COVID-19. The global population has been anxiously waiting for a potential vaccine for more than a year by now. As of February 2021, eleven vaccine candidates were approved in less than a year's time by at least one national regulatory body for public use: two RNA based (Pfizer-BioNTech and Moderna vaccine), four conventional inactivated vaccines (BBIBPCorV, Covaxin, CoronaVac and CoviVac), four viral vector vaccines (Sputnik V, Oxford-AstraZeneca, Convidicea and Johnson \& Johnson), and one peptide vaccine (EpiVacCorona) (LSHTM, 2021). As of 24 February 2021, 221.8 million doses of COVID19 vaccine were administered worldwide. It included 12.3 million from India since 16th January, 2021. According to the recent data, retrieved on March 30, 2021 (Mathieu, 2021), against 63.1 million administered doses, only 9.07 million have been fully vaccinated i.e., $0.66 \%$ of the population in India. The dismal number of vaccinated individuals is a possible indicator of the hesitance among the public of various countries, attributable to the fear about the safety of the COVID-19 vaccine candidates used by the respective countries while the spread of misinformation cannot be ruled out (The Guardian, 2021). Despite the backing from the scientific fraternity, vaccine acceptance is shaped according to the dictates of space, time, social class, ethnicity, knowledge and attitude (Larson et al., 2014; Xiao et al., 2020; Shetty et al., 2019).

In some studies, executed before the COVID-19 vaccination program (when the spread was intensive with alarming number of cases, registered per day) had started in India, varied acceptance levels of $86.3 \%$ (Sharun et al. 2020), 77.3 \% (Gautam et al. 2020), 74.5 \% (Lazarus et al. 2021) and 74 \% (Kazi Abdul and Khandaker Mursheda, 2020) were recorded. Similarly, a high acceptance was observed in others countries like US (80 \%) (Thunstrom et al. 2020), and China (72.5 \%) (Fu et al. 2020) prior to vaccination. In our survey on knowledge and acceptance for COVID-19 vaccination, conducted during the 1 st phase of vaccination in India, we found around $70 \%$ acceptance among the 358 participants, hailing from different parts of the country. During our survey period (1st to 15th February, 2021), a comparatively lower intensity of spread (average 11,500 cases/day) was registered. Based on these results, it appears that the reduction in acceptance rate bears a correspondence with the dip in the intensity of the cases. This needs a deeper delving. However, on a note of concern, this level of acceptance towards COVID-19 vaccine projects to be inadequate to meet the requirements for immunizing large community.

The vaccination drive started on 16th January, 2021 in India and nearly, all the participants were aware about it: TV and social media, being the main sources of information. However, the lack of knowledge was evident in multiple 
instances. One third of the responders did not know about the indigenous vaccine candidate (Covaxin), cost of the vaccine (free) and non-mandatory policy. Most importantly, a quarter of the participants did not know about the requisite for the 2 nd dose post 28 days of the first shot for the completion of vaccination regime. In fact, as on February 13,2021 , only 7,668 out of the over 1, 91,000 participating healthcare workers, who were administered the first shot on 16 January, had shown up for the second dose of the COVID-19 jab, indicating a mere 4\% turn up (Money Control, 2021). Augmenting the acceptance demands the dissemination of timely and adequate knowledge and trust building for the current COVID-19 vaccination. In support of this, the central and state governments had allowed walkins, counselled and mobilized healthcare workers and promoted visible feedback from vaccinated individuals, leading to improved average turn up of $65 \%$ for the 2nd dose on 25th February, 2021 (Live Mint, 2021). Our study also revealed that the there was a positive correlation between knowledge and the acceptance of vaccination, in general. Interestingly, there was negative correlation between knowledge and acceptance in specific cases, to cite for evidence, the knowledge score (5.93/7) was more for the respondents from Tamil Nadu while their acceptance score (3.29/5) was lesser than the others. As a matter of fact, a lackluster $22 \%$ turnout was recorded in Tamil Nadu in the first two days of the vaccination drive in January, 2021 (The Guardian, 2021). The respondents from Delhi had the acceptance score of 4.36 against a knowledge score of 5.17 .

Most of the respondents (66\%) felt that the currently administered COVID-19 vaccines were safe, however, $30 \%$ respondents exhibited an attitude of fear, while $22 \%$ registered a 'neutral' attitude. Around $44 \%$ of the respondents were of the view that possibility of side effect was the major reason for the hesitance to accept, followed by the lack of data on sufficient clinical trials while one out of ten chose the 'I don't know' response. In agreement with our study, Khan et al. (2020) also reported that apprehension about possible side effects acted as the key barrier to vaccine acceptance in India. Indian government had laid its precedence on the healthcare and frontline workers during the 1st phase of vaccination. On a surprising note, we found that the healthcare workers had shown greater negative acceptance level than others. This might be attributed to the insufficiency of clinical safety data and the associated anxiety of being the prime beneficiaries in the 1st phase. Execution of greater number of studies to assess the effectiveness and safety of vaccines is imperative. Counselling, mobilization and feedback from vaccinated individuals about the safety should be encouraged. Previous studies on pandemics, caused by H1N1, SARS, MERS and Ebola, are suggestive of the fact that successful disease control depends on trusted sources of information and guidance to a great extent (Larson et al. 2014; Larson et al. 2018). However, Siegrist, and Zingg (2014)'s remark about the multifactorial, intricate and context-dependent attribute of vaccine hesitancy, that demands concomitant tackling at various levels merit special mention. Understanding patient-physician interactions in the context of vaccine hesitancy is also critical.

The participants, belonging to the masculine gender, age $>29$ years, married, more educated, engaged in government jobs and those in the urban areas registered higher knowledge score. This may be plausibly attributed to the difference in the accessibility-levels of information in comparison to their counterparts. The same trend was noted for the acceptance, except across the demographic variables of education and area. On an interesting note, less educated people and rural participants exhibited greater positive acceptance than their counterparts. In lines with our observation, Al-Mohaithef and Padhi (2020) had reported greater acceptance among participants, belonging to the masculine gender, age above 45 years, married, higher level of education and government employees in Saudi Arabia. Another global survey also supported similar finding except for the fact that females documented a greater positive acceptance than the males (Lazarus et al. 2021). In fact, nearly, $11 \%$ of the respondents exhibited negative acceptance while $18 \%$ was grouped under poor knowledge category. It is quite perceivable that trust and legitimacy are pivotal in grasping why some sources of information on vaccination are referred to more often than others, how information on vaccination is re-interpreted and the way beliefs that are often conflicting to medical science are

Page 13/19 
shaped (Yaqub et al. 2014). These might provide some backdrop to understand and unsnarl some perplexing observations, evident in our study as well, such as why the better/higher educated people (who mistrust) might reject vaccination more readily than the less educated (who accept passively) (Hak et al., 2005).

At this juncture, it is pertinent to mention that currently we do not have comprehensive data on the effectiveness of the current COVID-19 vaccines against the emerging variants of the virus (WHO, 2021) as well as the duration for which the immunity shall last post vaccination (Lord, 2021). However, Dr. V. K. Paul, Member (Health), NITI Aayog has recently mentioned about the availability of data to attest the safety and effectiveness of the vaccines against both, Brazil and the U.K. variants of the novel coronavirus (Ministry of Health, 2021). Previously, it has been advocated that the awareness about the vaccines and vaccination program should be increased among the population; this can have profound role in reducing vaccine hesitancy (Gautam et al. 2020). When it comes to mass immunization, a transparent, evidence-based policy as well as clear, accurate and timely communication are indispensable. The current pandemic seems to be open up an opportunity-portal to build and fortify vaccine acquaintance and confidence among public towards the administration of potential COVID-19 vaccine.

\section{Limitations of the study}

This study had a number of limitations. The survey was conducted based on the respective online network of the authors and relied on the circulation of the survey link on different social media platforms for a certain period in time. There is a possibility of bias as underprivileged populations may not have been able to participate in the survey. Moreover, when compared to the current population in India, the survey-sample was over representative for participants below the age of 50 , students, and educated (more than a degree). The findings may not be a true representation from the perspective of the entire nation. A more systematic, community-based, inclusive sampling method (preferably conducted in local/official languages of different areas) is recommended to improve the representativeness and generalizability of the findings. Despite these limitations, our findings are expected to provide valuable information about the knowledge and acceptance toward current COVID-19 vaccination program among Indians. This could be crucial in shaping and chalking out necessary action-plans for further vaccine campaign.

\section{Conclusion}

This community based online survey on knowledge and attitude of acceptance for COVID-19 vaccine, conducted during the 1st phase of vaccination among Indians revealed that the majority of the participants had positive acceptance and good knowledge with positive correlation between the two. However, the positive acceptance for immunization from the larger perspective in the community was low. Significant difference was observed among the respondents with respect to knowledge while no significant difference in acceptance was noted across many demographical variables. A considerable number of participants were apprehensive about the safety of the vaccine. Dissemination of timely knowledge and education as well as safety and health promotion interventions, targeting concerned demographic variables are requisites of the moment. Studies with greater number of participants are expected to provide deeper insight and more convincing results. Nevertheless, the major findings of this study may be utilized in planning vaccination campaigns in further phases.

\section{Declarations}

\section{Acknowledgements}


A note of gratitude is extended to all the participants for responding and providing us with valuable online survey information. The authors extend a bouquet of gratitude to Dr. Rao Bhamidimarri, President, Institute of Advanced Research, Gujarat and Dr. Priti Desai, HoD, Department of Biotechnology, Institute of Advanced Research, Gujarat for the immediate approval and support for the survey.

\section{Data availability statement}

The datasets generated during and/or analyzed during the current study are available from the corresponding authors on reasonable request.

\section{Funding}

Though no formal funding was provided, this research was conducted using the resources and research priority directions of the Institute of Advanced Research, Gujarat.

Competing interests: The authors have declared that no competing interests exist.

\section{Authors Contribution}

Concept: Arumuganainar Suresh, Rocktotpal Konwarh,

Methodology: Arumuganainar Suresh, Rocktotpal Konwarh, Anand Pratap Singh, Anand Krishna Tiwari

Data analysis: Arumuganainar Suresh, Rocktotpal Konwarh, Anand Krishna Tiwari

Project administration: Arumuganainar Suresh, Rocktotpal Konwarh, Anand Pratap Singh

Supervision: Arumuganainar Suresh, Rocktotpal Konwarh, Anand Pratap Singh

Writing - original draft: Arumuganainar Suresh, Rocktotpal Konwarh

Writing - review \& editing: Arumuganainar Suresh, Rocktotpal Konwarh, Anand Pratap Singh, Anand Krishna Tiwari

\section{References}

Al-Mohaithef, M., Padhi, B.K., 2020. Determinants of COVID-19 vaccine acceptance in Saudi Arabia: a web-based national survey. Journal of Multidisciplinary Healthcare 13, 1657. https://doi.org/10.2147/JMDH.S276771

Covid19India, 2021. https://www.covid19india.org/

DNAINDIA, 2021. India's coronavirus vaccine candidate COVAXIN showed positive result in animals: Bharat Biotech (dnaindia.com)

Fu, C., Wei, Z., Pei, S., Li, S., Sun, X., Liu, P., 2020. Acceptance and preference for COVID-19 vaccination in health-care workers (HCWs). MedRxiv. https://doi.org/10.1101/2020.04.09.20060103

Gautam, A., Dhara, B., Mukherjee, D., Mukhopadhyay, D., Roy, S., Ganguly, S.S., Chowdhury, A.D., Goswami, S., Dey, S., Basu, S., Chatterjee, S., 2020. a digital survey on the acceptance and affordability of COVID 19 vaccine among the people of West Bengal, India-A survey based study. medRxiv https://doi.org/10.1101/2020.11.13.20229534 
Hak, E., Schönbeck, Y., De Melker, H., Van Essen, G.A. and Sanders, E.A., 2005. Negative attitude of highly educated parents and health care workers towards future vaccinations in the Dutch childhood vaccination

program. Vaccine, 23(24), 3103-3107. https://doi.org/10.1016/j.vaccine.2005.01.074

Hindustan Times, 2021. https://www.hindustantimes.com/india-news/only-4-beneficiaries-turn-up-for-secondvaccine-shot-centre-101613239833404.html

Kazi Abdul, M., Khandaker Mursheda, F., 2020. Knowledge, attitude and acceptance of a COVID-19 Vaccine: A global cross-Sectional study https://mpra.ub.uni-muenchen.de/105236/

Konwarh, R., 2020. Can CRISPR/Cas technology be a felicitous stratagem against the COVID-19 fiasco? Prospects and hitches. Frontiers in Molecular Biosciences 7, 557377. doi: 10.3389/fmolb.2020.557377

Konwarh, R., 2020b. Nanobodies: prospects of expanding the gamut of neutralizing antibodies against the novel coronavirus, SARS-CoV-2. Frontiers in Immunology 11, 1531. doi: 10.3389/fimmu.2020.01531

Konwarh, R., Cho, W. C., 2021. Fortifying the diagnostic-frontiers with nanoscale technology amidst the COVID-19 catastrophe. Expert Review of Molecular Diagnostics 21(2), 131-135, doi: 10.1080/14737159.2021.1878879

Lane, S., MacDonald, N.E., Marti, M., Dumolard, L., 2018. Vaccine hesitancy around the globe: Analysis of three years of WHO/UNICEF Joint Reporting Form data-2015-2017. Vaccine, 36(26), 3861-

3867. https://doi.org/10.1016/j.vaccine.2018.03.063

Larson, H.J., Clarke, R.M., Jarrett, C., Eckersberger, E., Levine, Z., Schulz, W.S. and Paterson, P., 2018. Measuring trust in vaccination: A systematic review. Human Vaccines \& Immunotherapeutics, 14(7), 1599-1609.

https://doi.org/10.1080/21645515.2018.1459252

Larson, H.J., Jarrett, C., Eckersberger, E., Smith, D.M., Paterson, P., 2014. Understanding vaccine hesitancy around vaccines and vaccination from a global perspective: a systematic review of published literature, 20072012. Vaccine, 32(19), 2150-2159. https://doi.org/10.1016/j.vaccine.2014.01.081

Lazarus, J.V., Ratzan, S.C., Palayew, A., Gostin, L.O., Larson, H.J., Rabin, K., Kimball, S., El-Mohandes, A., 2021. A global survey of potential acceptance of a COVID-19 vaccine. Nature Medicine, 27, 225-

228. https://doi.org/10.1038/s41591-020-1124-9

Live Mint, 2021. https://www.livemint.com/news/india/delhi-j-k-lead-phase-1-vaccine-effort-second-dose-turnoutlowerthanexpected-11614235546595.html

Lord, D., 2021. Coronavirus: How long does immunity last after a COVID-19 vaccine? https://www.kiro7.com/news/trending/coronavirus-how-long-does-immunity-last-after-covid-19vaccine/RIMEAWEUWRE6PG6CT4KZEN2NYE/

LSHTM, 2021. London School of Hygiene and Tropical Medicine. Equity of vaccine roll-out COVID-19 vaccine tracker (shinyapps.io)

MacDonald, N.E., 2015. Vaccine hesitancy: Definition, scope and determinants. Vaccine, 33(34), pp.41614164. https://doi.org/10.1016/j.vaccine.2015.04.036 
Mathieu, E., 2021. Owid/COVID-19 data. https://github.com/owid/covid-19-

data/blob/master/public/data/vaccinations/vaccinations.csv

Ministry of Health (@MoHFW_INDIA), 2021 https://twitter.com/MoHFW_INDIA/status/1377980071152021509?

ref_src=twsrc\%5Egoogle\%7Ctwcamp\%5Eserp\%7Ctwgr\%5Etweet

Ministry of Health and Family Welfare, Govt. of India,

2021. https://www.mohfw.gov.in/covid_vaccination/vaccination/faqs.html\#about-the-vaccine

Money Control, 2021. COVID-19 Vaccination | Most Beneficiaries Skipped Second Dose, Reveals Government Data (moneycontrol.com)

Our World in Data, 2021. https://ourworldindata.org/covid-vaccinations

Sharun, K., Rahman, C.F., Haritha, C.V., Jose, B., Tiwari, R., Dhama, K., 2020. COVID-19 vaccine acceptance: Beliefs and barriers associated with vaccination among the general population in india. Journal of Experimental Biology and Agricultural Sciences, 8(Special Issue 1). http://dx.doi.org/10.18006/2020.8(Spl-1-SARS-CoV-2).S210.S218

Shetty S, Prabhu S, Shetty V, Shetty AK., 2019. Knowledge, attitudes and factors associated with acceptability of human papillomavirus vaccination among undergraduate medical, dental and nursing students in South India. Human vaccines \& Immunotherapeutics. 15(7-8), 1656-65. https://doi.org/10.1080/21645515.2019.1565260

Siegrist, M., Zingg, A. 2014. The role of public trust during pandemics: implications for crisis communication European Psychologist, 19, 23-32. https://psycnet.apa.org/doi/10.1027/1016-9040/a000169

The Guardian, 2021. Indian hesitancy sets back world's biggest Covid vaccination drive | World news | The Guardian

The Hindu, 2021. Coronavirus | Over six lakh vaccinated so far - The Hindu

Thunstrom, L., Ashworth, M., Finnoff, D., Newbold, S., 2020. Hesitancy towards a COVID-19 vaccine and prospects for herd immunity. Available at SSRN 3593098. https://dx.doi.org/10.2139/ssrn.3593098

WHO, 2021. The effects of virus variants on COVID-19 vaccines. https://www.who.int/news-room/featurestories/detail/the-effects-of-virus-variants-on-covid-19-vaccines

Worldometer, 2021. https://www.worldometers.info/coronavirus/?utm_campaign=homeAdvegas1?\#countries

Xiao, X., Wong, R.M., 2020. Vaccine hesitancy and perceived behavioral control: A meta-analysis. Vaccine, 38(33), 5131-5138. https://doi.org/10.1016/j.vaccine.2020.04.076

Yaqub, O., Castle-Clarke, S., Sevdalis, N. and Chataway, J., 2014. Attitudes to vaccination: a critical review. Social Science \& Medicine, 112, 1-11. http://dx.doi.org/10.1016/j.socscimed.2014.04.018

\section{Figures}




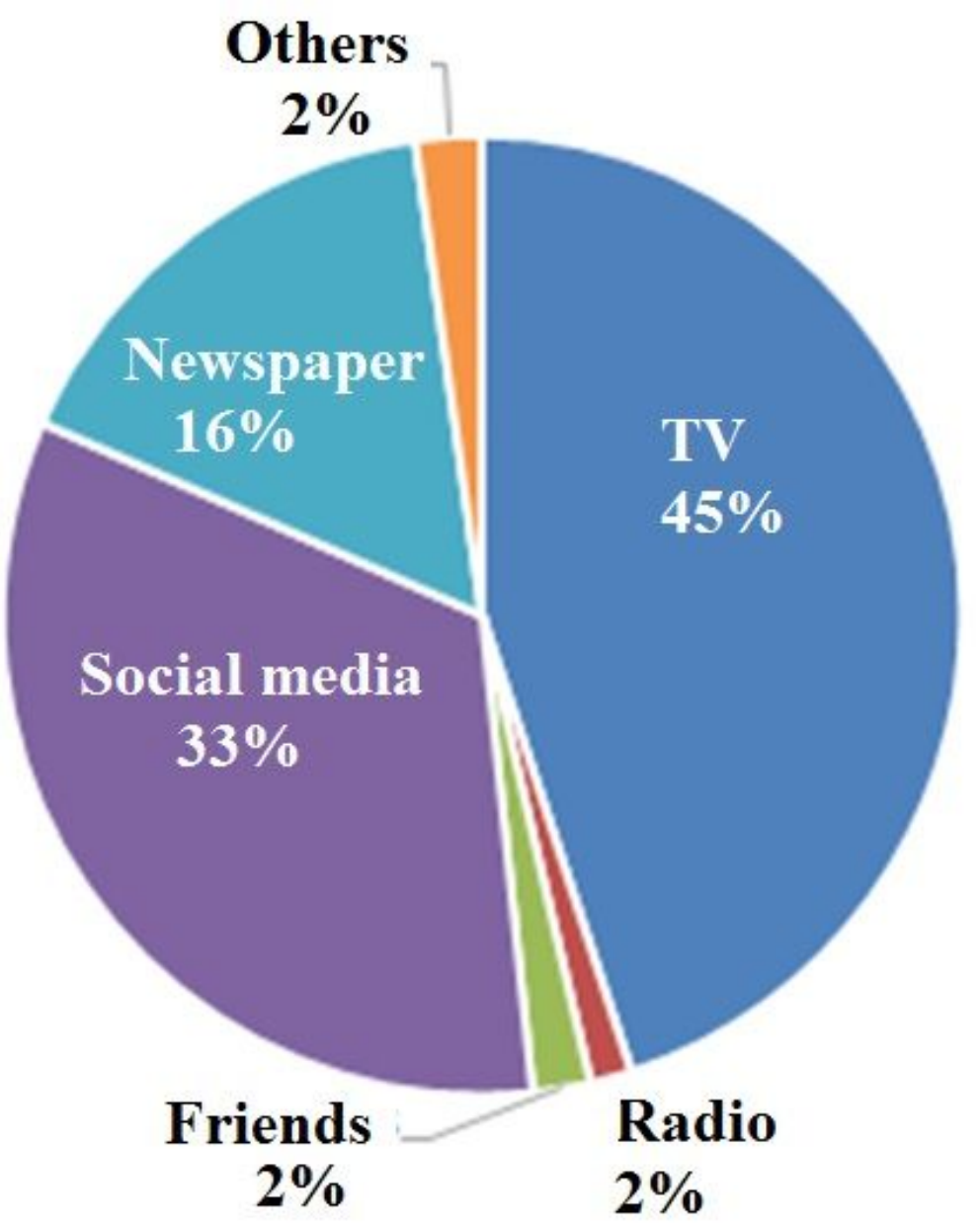

\section{Figure 1}

Pie-chart, depicting the share (in percentage) of the various sources of information about the COVID-19 vaccination program in India among the respondents 


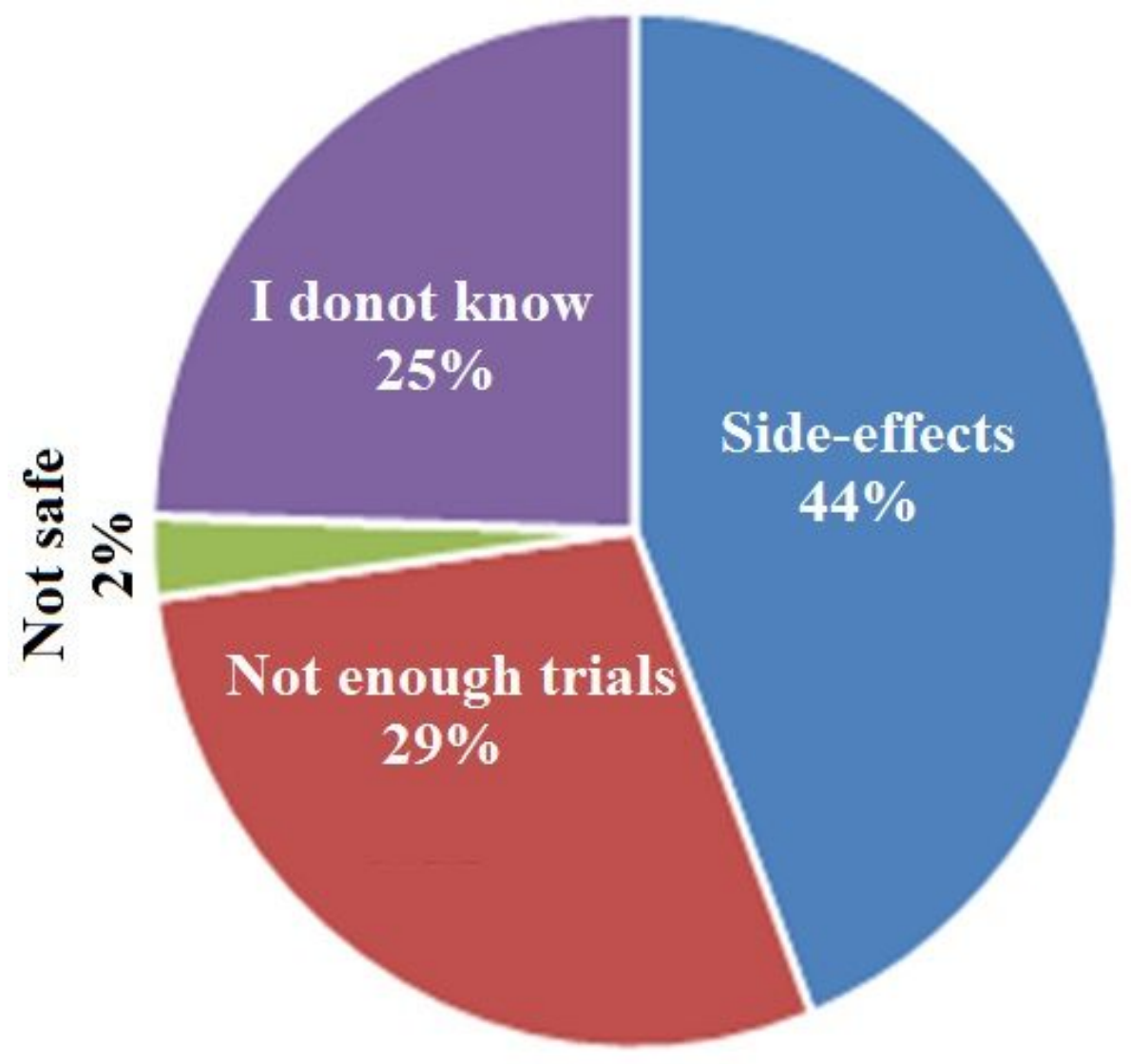

\section{Figure 2}

Pie-chart, depicting the response to the query, 'Why are you hesitant/afraid to take the COVID-19 vaccine?'

\section{Supplementary Files}

This is a list of supplementary files associated with this preprint. Click to download.

- ElectronicSupplementaryFigure1.tif 